\title{
Luiz Gama:
}

\section{um abolicionista leitor de Renan}

\author{
LIGIA FONSECA FERREIRA
}

$\mathrm{N}$ A SEGUNDA metade do século XIX, atores importantes do regime escravista e figuras emblemáticas do movimento abolicionista no Brasil abraçaram as idéias de Ernest Renan (1823-1892). A exemplo de outros pensadores franceses, sua influência marcou uma geração de homens que sofreram ou prepararam o declínio do Segundo Império, tarefa que os obrigaria a enfrentar dilemas conceituais e ideológicos, tais como as relações entre Igreja e Estado, Monarquia e República, raça e nação.

Por ocasião do ano do Brasil na França em 2005, a Universidade de Rennes 2 - Haute Bretagne organizou colóquios em torno das relações entre a Bretanha e o Brasil, um deles dedicado ao historiador, filólogo e filósofo bretão. ${ }^{1}$ Nascido na cidade de Tréguier, com pouco mais de vinte anos o ex-seminarista versado em filologia hebraica e exegese vê abalada sua fé católica e, movido pelo ideal do cientificismo, empreende uma vasta história crítica do cristianismo. Seu pensamento forneceu subsídios à posição do governo brasileiro perante o Vaticano durante a crise desencadeada pela chamada Questão Religiosa, para citar apenas um exemplo. Entre seus admiradores brasileiros encontram-se figuras contrastantes: de um lado, membros da elite política e econômica como o próprio imperador Dom Pedro II (1825-1891) e Joaquim Nabuco (1849-1910), filho e neto de senadores; de outro, um ex-escravo, Luiz Gama. Três homens, enfim, separados sob inúmeros aspectos, das origens sociais e raciais às posturas ideológicas.

O presente artigo pretende evocar a influência de Renan, hoje um tanto esquecida, num personagem que, pouco a pouco, vem sendo retirado dos bastidores da memória nacional. Inicialmente, referiremos alguns dados biográficos a fim de elucidar o lugar de Luiz Gama (1830-1882) no seio da elite intelectual e política brasileira e seu papel de vanguarda no movimento abolicionista. Em seguida, avaliaremos em que condições acontece e que impactos produz sua leitura de Renan, uma vez que, não tendo o domínio do francês, possuía acesso limitado a obras escritas nesse idioma. Por fim, verificaremos em que medida o pensamento do historiador bretão funda a ética de um homem que encarnou a luta pelo fim da escravidão e pelos ideais republicanos no Brasil e, em particular, na província de São Paulo.

Poeta, jornalista e advogado, Luiz Gama é um dos raros intelectuais negros brasileiros do século XIX, o único autodidata e o único, também, a ter vivido 
a experiência da escravidão antes de obter "ardilosa e secretamente", conforme assinala numa correspondência, as provas de ter nascido livre. ${ }^{2}$ Provar e conservar a liberdade não é algo evidente para um negro no século XIX. Mas esse é apenas um capítulo isolado de uma "biografia de novela" (Fausto, 1994, p.219), pontuada por momentos candentes do Segundo Império e na qual se sucedem catástrofes e reviravoltas. $\mathrm{O}$ caminho trilhado pelo ex-escravo analfabeto alçado ao status de cidadão foi longo e árduo. É preciso lembrar que, antes de 1889, a palavra "cidadão" não era apenas sinônimo de "homem livre". Empregava-se também por oposição a "súdito" no vocabulário dos antimonarquistas de extração liberal ou republicana que, como Luiz Gama, atacavam com virulência o governo de Dom Pedro II.

Por volta de 1880, o prestígio de Luiz Gama, então com cinqüenta anos (ele falecerá seis anos antes da Abolição e sete anos antes da Proclamação da República), era alto e ultrapassava as fronteiras de São Paulo, onde era considerado um dos "melhores cidadãos" (Mendonça, 1880, p.50) da cidade onde viveu por 42 anos. Nascido em 1830 em Salvador, Gama é fruto de uma mistura luso-africana, ou seja, de uma "raça inferior" com uma "raça nobre", conforme escreve Renan em carta ao teórico das desigualdades raciais, Arthur de Gobineau. Tratava-se de uma "imisção" nefasta suscetível de "envenenar a espécie humana", ${ }^{3}$ tese da qual o híbrido brasileiro se revelaria um perfeito contra-exemplo.

Gama se dizia filho de uma africana livre, Luiza Mahin, pintada como uma mulher "altiva, geniosa, insofrida e vingativa" (in Moraes, 2005, p.69), envolvida em revoltas negras como as inúmeras que agitam a Bahia dos anos 1830. Contrariamente, porém, ao que sonharam alguns a partir de uma interpretação fantasiosa do que escrevera Luiz Gama, atribuiu-se equivocadamente à mítica Luiza Mahin um papel de liderança jamais comprovado na Revolta dos Malês (Reis, 2003, p.303). Luiz Gama, no entanto, alude à adesão de seus pais a um outro levante baiano. Sua mãe teria se dirigido ao Rio de Janeiro, ali desaparecendo, após a "Revolução do Dr. Sabino" em 1837, movimento que proclama uma república provisória em repúdio ao poder monárquico central, a exemplo do que ocorria em outro ponto do país, como a Revolução Farroupilha. Quanto à figura paterna, é também descrita como a de um "revolucionário em 1837", pertencente a "uma das principais famílias da Bahia de origem portuguesa" (in Moraes, 2005, p.70). Luiz Gama, porém, jamais revelaria o nome do pai que o vende aos dez anos de idade como escravo, protagonizando o primeiro dramático episódio de sua existência. Aos dezoito anos, aprende a ler e a escrever e consegue as provas de ter nascido livre.

Em menos de doze anos, o ex-escravo entra para o mundo das letras, um mundo quase exclusivo de brancos, graças à publicação da sua obra única Primeiras trovas burlescas, coletânea de poemas líricos e de sátira social e política (Gama, 1859, 1861). ${ }^{4}$ Pela primeira vez na literatura brasileira, ouve-se uma voz negra. Depois de provar o sucesso e a legitimação propiciadas pela publicação de seu livro, em meados dos anos 1860 Luiz Gama inicia suas atividades na imprensa paulistana onde desempenha um papel histórico. Ao lado do desenhista 
italiano Ângelo Agostini (1843-1910), ${ }^{5}$ ajuda a fundar os primeiros periódicos ilustrados de São Paulo, o Diabo Coxo (1864-1865) e Cabrião (1866-1867), publicações fortemente marcadas por posturas anticlericais e antimonárquicas, temas recorrentes nos escritos de Gama. A partir de então, ele se firma na cena pública. $\mathrm{O}$ autodidata se torna advogado, embora não tivesse freqüentado nenhuma escola nem a Faculdade de Direito (uma licença especial para exercer a profissão podia ser dispensada a pessoas que comprovassem competências na matéria jurídica). Gama encarnava, para o desassossego de seus detratores, a crença sintetizada numa de suas sentenças: "A inteligência repele os diplomas como Deus repele a escravidão" ${ }^{6}$ A imprensa e os tribunais convertem-se em palcos privilegiados para os combates daquele homem animado pelo sonho de um "Brasil americano e as terras do Cruzeiro sem reis e sem escravos".

O advogado dos escravos deixou sua marca na capital paulista, e seu destino não teria sido o mesmo em outro lugar. Contrariamente ao Rio ou Salvador, cidades com acentuada presença de negros e mulatos, mesmo entre os membros de suas elites, em São Paulo Luiz Gama é uma exceção. Sua vida se tece com os fios da história e do desenvolvimento da cidade inexpressiva e provinciana à qual chega na condição de escravo em 1840, cidade que trinta anos depois se torna a metrópole do café. As plantações do interior concentram um número crescente de escravos. Por volta de 1870, São Paulo é uma das principais províncias negreiras do país. A ação abolicionista de Luiz Gama e de seu grupo ali encontraria, pois, sua plena justificação. Com uma população quase dez vezes inferior e sem o brilho da corte, a capital paulista se caracterizaria, ademais, por uma forte cultura jurídica e de feição liberal, já que, além de Recife, é a única a acolher desde 1828 uma Faculdade de Direito que afeta a pacata atmosfera e os hábitos da cidade. Chegam ali jovens de diversas regiões do país, filhos de abastadas famílias da oligarquia rural, mas também de segmentos socioeconômicos que se diversificam ao longo do tempo, razão pela qual Luiz Gama, proprietário e redator do semanário $O$ Polichinelo, define a instituição acadêmica como uma "Arca de Noé em ponto pequeno". ${ }^{8}$

Ao compartilhar experiências, aqueles futuros advogados, magistrados, jornalistas, administradores, professores ou políticos passavam a ter uma visão global do Brasil, abandonando o prisma regional que entravava a consolidação da independência e de um real sentimento ou idéia de nação. A variedade das regiões representadas nesse microcosmo inspiraria, assim, uma "civilidade" mais "cívica" do que a que talvez emanasse da corte, como escreve Gilberto Freyre no prefácio a História e tradições da cidade de São Paulo (Bruno, 1953, p.xiv). A mentalidade dos jovens membros das elites brasileiras impregna-se da "educação liberal típica das faculdades de direito brasileiras", onde adquirem uma concepção nova dos problemas do país do qual um dia muitos virão a ser os dirigentes (Adorno, 1988).

Se a ciência jurídica fascina Luiz Gama, a Faculdade de Direito e seus doutores são alvos freqüentes de seu sarcasmo e indignação desde as Primeiras trovas 
burlescas. Entre 1869 e 1870, nas colunas que mantinha no Radical Paulistano, órgão do Partido Liberal Radical, ${ }^{9}$ o polêmico advogado e jornalista trazia a público os erros de jurisprudência cometidos por juízes incautos, corruptos ou incompetentes, analisando pormenorizadamente sentenças de toda ordem proferidas nos foros da capital ou do interior. Além de instruir seus leitores, o exercício permitia-lhe exibir sua vasta cultura jurídica e uma posição de superioridade ante os doutores. Luiz Gama evolui cotidianamente no universo jurídico, do qual fazem parte também seus principais aliados. Seu amigo e protetor, conselheiro Furtado de Mendonça, chefe da polícia de São Paulo, a quem Luiz Gama dedica as Primeiras trovas burlescas, é professor e bibliotecário-chefe da Faculdade de Direito, o que nos autoriza supor que, graças a ele, Luiz Gama, leitor voraz, teve acesso àquele recinto. Um de seus melhores amigos, o chefe liberal José Bonifácio, o moço, autor de poesias que Luiz Gama publica como anexo nas duas edições de seu livro, integra o corpo docente daquela instituição. Junto aos estudantes, Gama desfrutará de grande popularidade até o fim da vida.

No final dos anos 1860, passam pela Faculdade de Direito homens que viriam a ter destacada atuação na vida literária e política brasileira. O jovem Castro Alves escreve em São Paulo o poema Os escravos e declama-o pela primeira vez na homenagem prestada pelos liberais paulistas a José Bonifácio que retornava à sua província de origem após a queda de Zacharias de Góis e Vasconcelos em 1868. Rui Barbosa é membro fundador, ao lado de Luiz Gama, da ativíssima loja maçônica "América", onde apresentara em 1869 um anteprojeto para a emancipação das crianças escravas. Nessa mesma loja, o então estudante de direito Joaquim Nabuco, que em momento algum evoca seu passado maçônico, teria sido iniciado seis meses antes de Rui Barbosa, cuja iniciação ocorreu em julho de 1869 (Ferreira, 2001, p.326).

A temporada paulista molda o espírito de muitos homens que, durante sua formação acadêmica, fazem a descoberta de Ernest Renan. Joaquim Nabuco $(1948$, p.13) dá um dos testemunhos mais expressivos quando, em Minha formação, ele conta, em tom superlativo, o impacto de certas leituras no jovem estudante de direito em São Paulo:

Quando entrei para a Academia [de Direito], levava a minha fé católica virgem; sempre me recordarei do espanto, do desprezo, da comoção com que ouvi pela primeira vez tratar da Virgem Maria em tom libertino; em pouco tempo, porém, não me restava daquela imagem senão o pó dourado da saudade [...] Basta-me dizer, por enquanto, que a grande influência literária que experimentei na vida, a embriaguez do espírito mais perfeita que se podia dar, pelo narcótico de um estilo de timbre sem igual em nenhuma literatura, o meu coup de foudre intelectual, foi a influência de Renan.

Como ele, muitos de seus colegas perdem a fé e convertem-se em aguerridos contestatários da Igreja. Embora na idade madura retornasse à religião, o entusiástico Nabuco não tardaria a travar conhecimento com aquele a quem chamava de "divin maître". Em 1872, publica no Rio de Janeiro uma carta em 
francês intitulada "Le droit au meurtre" dirigida a Renan, na qual comenta o desfecho de uma obra de Alexandre Dumas. O opúsculo logo chegou às mãos do destinatário com o qual Nabuco passa a se corresponder e, no ano seguinte, em viagem à Europa, visita-o nos primeiros dias de sua estada na capital francesa. O encontro causou verdadeiro "encantamento" naquele brasileiro de nobre estirpe, de ambições intelectuais e literárias tão amplas quanto a trajetória política que apenas começava. Graças às cartas de recomendação de Renan, aproveitou sua passagem por Paris para entrevistar-se com várias personalidades, como os positivistas Taine e Littré, ou ainda o presidente Adolphe Thiers (ibidem, 80-1). Mas, além de Nabuco que se descreve em suas memórias como renanista paradigmático, são diversos, e de perfil distinto do seu, os primeiros brasileiros a se encantarem com as idéias do pensador francês a partir dos anos 1860 .

Daqui por diante, concentrar-nos-emos sobre um período capital que se estende de 1864 a meados dos anos 1870, marcado por uma guerra e por mudanças de mentalidade no país. O saldo da Guerra do Paraguai anuncia o declínio do reinado de Dom Pedro II. O conflito deixava expostas as chagas e a não-sustentabilidade do escravismo brasileiro, sobre o qual pairava, igualmente, o fantasma da trágica Guerra de Secessão que culminara com abolição da escravatura nos Estados Unidos. O Brasil adquiria, assim, a incômoda e solitária posição de último país de regime monárquico e escravagista nas Américas, apesar de um primeiro passo ter sido dado com a promulgação da Lei do Ventre Livre, sem, contudo, provocar uma efetiva aceleração do processo para a emancipação dos escravos. Na cena política, o fosso entre conservadores e liberais se acentua. Uma cisão entre estes últimos leva à criação, em 1868, do Partido Radical Liberal, que contribuirá para a rápida disseminação dos ideais republicanos também gerados, em São Paulo, na Faculdade de Direito e na maçonaria paulista. Em São Paulo, o influente Partido Republicano Paulista (PRP), fundado em abril de $1873 \mathrm{com}$ a participação da oligarquia cafeeira, assenta-se desde o início sobre contradições de princípio, sob protestos veementes de um solitário Luiz Gama. ${ }^{10}$

No final dos anos 1860, assiste-se igualmente a uma renovação intelectual e ideológica sob o influxo de pensadores europeus, especialmente os franceses Renan, Taine e Comte, respectivamente os autores mais citados por José Veríssimo nos ensaios reunidos em Homens e coisas estrangeiras. Conforme assinala Silvio Romero (1926, p.xxiii), um "bando de idéias novas" - positivismo, evolucionismo, crítica religiosa, transformações do direito e da política, realismo e naturalismo - pairou sobre as cabeças de brasileiros de ponta a ponta ansiosos por reformar o país. Por fim, a partir dos anos 1860, Luiz Gama vê crescer sua notoriedade em toda a província onde se encontra um dos mais resistentes bastiões do escravismo. ${ }^{11}$

$\mathrm{Na}$ vanguarda das idéias liberais e republicanas, em permanente tensão com forças conservadoras, a capital paulista se distingue das duas maiores cidades do país, Rio e Salvador, pelas características particulares que assume a campanha abolicionista da qual Luiz Gama será um dos principais atores. A 
sorte de centenas de negros encontrou-se entre as mãos de um homem que desembaraçava as situações mais inextricáveis de maneira hábil e ousada. Longe de desprezar suas origens e embranquecer socialmente, em um de seus últimos artigos, Gama (1944, p.185-6) resume, de forma dramática e nervosa, três séculos de exploração dos seres com os quais compartilhava vivência angustiosa e o estigma da cor:

Sim! Milhões de homens livres, nascidos como feras ou como anjos, nas fúlgidas areias da África, roubados, escravizados, [açoitados], mutilados, arrastados neste país clássico da sagrada liberdade, assassinados impunemente, sem direitos, sem família, sem pátria, sem religião, vendidos como bestas, espoliados em seu trabalho, transformados em máquinas, condenados à luta de todas as horas e de todos os dias, de todos os momentos, em proveito de especuladores cínicos, de ladrões impudicos, de salteadores sem nome; que tudo isso sofreram e sofrem, em face de uma sociedade opulenta, do mais sábio dos monarcas, à luz divina da santa religião católica, apostólica, romana, diante do mais generoso e mais interessado dos povos; que recebiam uma carabina envolvida em uma carta de alforria, com a obrigação de se fazerem matar à fome, à sede e à bala nos esteiros paraguaios e que nos leitos dos hospitais morriam, volvendo os olhos ao território brasileiro, os que, nos campos de batalha, caíam, saudando risonhos o glorioso pavilhão da terra de seus filhos; estas vítimas que, com seu sangue, com seu trabalho, com sua jactura, com sua própria miséria constituíram a grandeza desta nação, jamais encontraram quem, dirigindo um movimento espontâneo, desinteressado, supremo, lhes quebrasse os grilhões do cativeiro!...

As ações e os métodos empreendidos por Luiz Gama refletem as particularidades de um movimento iniciado vinte anos antes da abolição, quando as tensões provocadas pela Guerra do Paraguai ameaçam o edifício monárquico e escravista. Na realidade, o movimento abolicionista tomara ímpeto ao menos uns dez anos antes de 1879/1880, data apontada por Nabuco como a do surgimento da campanha. ${ }^{12}$ Em 1868, portanto, motivado pelas sucessivas derrotas do exército brasileiro no Paraguai, Dom Pedro II, soberano à frente de uma monarquia parlamentar, dissolve o governo liberal de Zacarias de Góis e Vasconcelos, cedendo às pressões conservadoras. A ascensão desses homens comprometidos com o regime servil põe freio à promessa feita pelo próprio imperador em 1867, no auge da guerra, de emancipar os escravos em breve. Os efeitos da nova maré se espraiam em todos os níveis da vida pública. De julho a novembro de 1868, o Correio Paulistano estampa quase diariamente a lista dos funcionários públicos demitidos, dos parlamentares liberais cassados, das vítimas de assassinatos. O turbulento Luiz Gama não escaparia à onda de demissões em massa. Em 1880, ele dá sua versão dos fatos:

Em $1856[\ldots]$ fui nomeado amanuense da Secretaria de Polícia, onde servi até 1868, época em que "por turbulento e sedicioso" fui demitido a "bem do serviço público", pelos conservadores, que então haviam subido ao poder [...] A turbulência consistia em fazer eu parte do Partido Liberal; e, pela imprensa e pelas urnas, pugnar pela vitória de minhas e suas idéias; e promover processos em favor 
de pessoas livres criminosamente escravizadas; e auxiliar licitamente, na medida de meus esforços, alforrias de escravos, porque detesto o cativeiro e todos os senhores, principalmente os reis. (Gama in Moraes, 2005, p.74-5)

O clima de represálias continuará por algum tempo. À medida que ganha voz própria, Luiz Gama rompe as relações de dependência com homens poderosos que buscavam entravar as ações do "cidadão". Numa sociedade escravista assentada no princípio de desigualdade e nas relações de força, um ex-escravo não poderia assumir o papel de defensor dos escravos sem incomodar os representantes do establishment e as instituições que sem trégua denuncia. Em dezembro de 1869, ele leva a conhecimento público, por meio de uma série de artigos publicados no Correio Paulistano (Ferreira, 2001, v.III, p.744-51), as razões de seu rompimento com Furtado de Mendonça depois de ser acusado de se envolver indevidamente com causas de liberdade. Com efeito, naquele ano a atuação política de Luiz Gama foi intensa. Ele se encontra entre os fundadores do Clube Radical Paulistano. Entre os sócios, encontram-se os “irmãos” da Loja América, cujas atividades, especialmente no tocante ao pecúlio destinado à manumissão de escravos, são sempre mencionadas nas páginas do Radical Paulistano, órgão daquela entidade. Intransigentes, os liberais radicais não acreditam, como os liberais moderados, na "extinção gradual do elemento servil", assim como não toleravam o "Rei tirano" que concentra em suas mãos o poder executivo e o poder moderador (Radical Paulistano, 17.5.1869). É também Luiz Gama quem inaugura e profere boa parte das conferências organizadas pelo Clube Radical, às quais comparecem centenas de paulistanos para ouvi-lo atacar seus alvos preferenciais, o governo imperial e a hipocrisia escravista (Ferreira, 2001, p.351-2).

Abandonando o lugar e a conduta prevista para pessoas de sua condição, o ex-escravo parte para o confronto, desmascarando uma "impostura perversa" (Comparato, 2007), ou seja, a não-aplicação de uma lei em princípio vigente mas deixada no limbo por mais de quarenta anos. Luiz Gama fala de um mundo às avessas, trazendo à tona o conluio e o jogo de faz-de-conta promovido por um governo e por seus representantes fora-da-lei:

Em vista do movimento abolicionista que se está desenvolvendo no império, a despeito [...] dos inauditos desplantes do seu imoral governo, começam de acautelar-se (sic) os corrompidos mercadores de carne humana.

As vozes dos abolicionistas têm posto em relevo um fato altamente criminoso e assaz defendido, há muitos anos, pelas nossas indignas autoridades. É o fato que a maior parte dos escravos africanos existentes no Brasil foram importados depois da lei proibitiva do tráfico promulgado em [7 de novembro de] 1831. Começam[,] amedrontados pela opinião pública, os possuidores de africanos livres a vendê-los para lugares distantes dos de sua residência.

Da [...] província de Minas Gerais, acaba, um sr. Antonio Gonçalves Pereira, de enviar para esta província os africanos Jacinto e sua mulher para serem aqui vendidos, isto porque é ali sabido e muito se falava ultimamente, que tais africanos foram importados há 20 anos!... 
Podemos afirmar que em idênticas circunstâncias existem muitos africanos nesta cidade, com conbecimento das autoridades, que são as principais protetora[s] de crime tão horroroso.

E mais afirmamos, que o governo de S. M. o Imperador tem dado a essas autoridades instruções secretas, para que não tomem conbecimento das reclamações que em tal sentido lhes forem feitas!...

Deverão os amigos da humanidade, os defensores da moral cruzar os braços diante de tão abomináveis delitos? (Radical Paulistano, 30.9.1869 - grifos do autor)

Os sucessos espetaculares obtidos pelo advogado negro transcendem as fronteiras de São Paulo. Escravos de outras províncias acorrem à capital paulista em busca do auxílio daquele homem disposto, quando necessário, a acoitá-los em sua própria casa, bem como da rede de solidariedade montada pelos membros da Loja América. Terror dos fazendeiros, o advogado imbatível recebeu mais de uma ameaça de morte por defender causas da liberdade. Assim, em 23 de setembro de 1870, ele deixa um bilhete ao seu filho, Benedito Graco Pinto da Gama, então com dez anos de idade, provavelmente antes de sair para tratar de algum processo grave envolvendo as propriedades de alguma figura poderosa. É nessa mensagem que ele faz menção ao nome de Renan e ao modelo que uma de suas obras lhe inspira:

Meu filho,

Dize a tua mãe que a ela cabe o rigoroso dever de conservar-se honesta e honrada; que não se atemorize da extrema pobreza que lego-lhe, porque a miséria é o mais brilhante apanágio da virtude.

Tu evita a amizade e as relações dos grandes homens; porque eles são como o oceano que aproxima-se das costas para corroer os penedos.

Sê republicano, como o foi o Homem-Cristo. Faze-te artista; crê, porém, que o estudo é o melhor entretenimento, e o livro o melhor amigo.

Faze-te apóstolo do ensino, desde já. Combate com ardor o trono, a indigência e a ignorância. Trabalha por ti e com esforço inquebrantável para que este país em que nascemos, sem rei e sem escravos, se chame Estados Unidos do Brasil. Sê cristão e filósofo; crê unicamente na autoridade da razão, e não te alies jamais a seita alguma religiosa. Deus revela-se tão somente na razão do homem, não existe em Igreja alguma do mundo.

Há dois livros cuja leitura recomendo-te: a Bíblia Sagrada e a Vida de Jesus por Ernesto Renan.

Trabalha e sê perseverante.

Lembra-te que escrevi estas linhas em momento supremo, sob a ameaça de assassinato. Tem compaixão de teus inimigos, como eu compadeço-me da sorte dos meus.

Teu pai

Luiz Gama. 


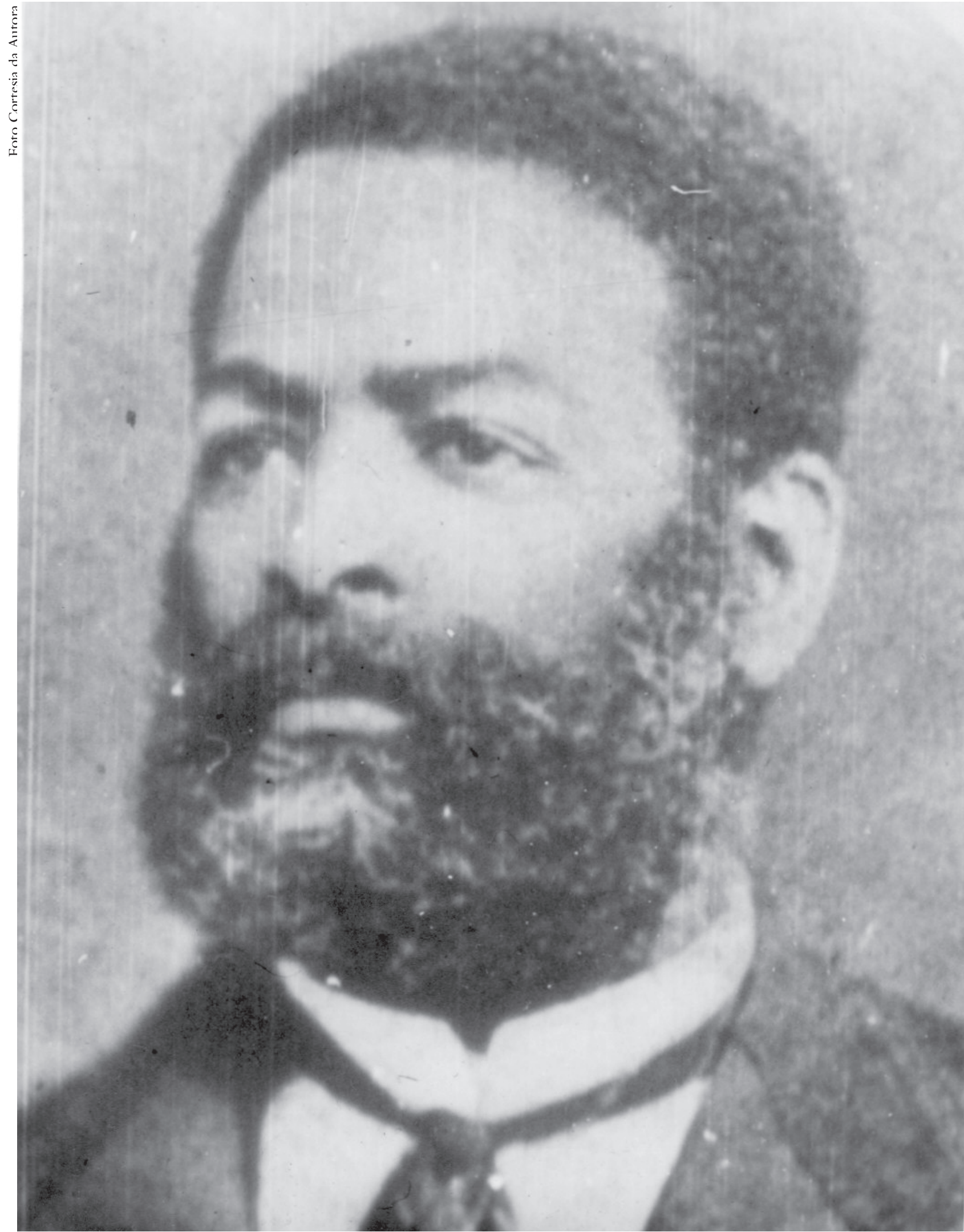

Luiz Gama (1830-1882). 
Os conselhos de um homem prestes a perder a vida e o convívio daqueles para quem representa o esteio constituem um verdadeiro testamento moral e espiritual. Escrita doze anos antes de sua morte, nessa mensagem ressoa a voz do republicano, do abolicionista, do maçom, ${ }^{13}$ de um amante da arte, da filosofia, da moral, da educação, temas caros aos liberais radicais e repisados em seus programas. Ninguém melhor do que um ex-escravo autodidata para testemunhar do fardo da ignorância que com muito custo conseguira superar numa sociedade onde a instrução é vetada aos cativos. Homem de caráter pragmático, Luiz Gama assume igualmente a missão de educar, o que faria por meio de ações concretas. O admirador de Renan, que em L'avenir de la science [O futuro da ciência] atribui os problemas da humanidade à falta de educação e cultura, monta uma biblioteca popular e cria um dos primeiros cursos noturnos para adultos na cidade com o auxílio da Loja América (Ferreira, 2001, p.335).

Luiz Gama recomenda duas leituras a seu filho, como se por si sós enfeixassem a sabedoria necessárias e suficientes para seu aperfeiçoamento intelectual e moral, aperfeiçoamento considerado pelo historiador francês como verdadeiro objetivo da humanidade. Curiosamente, as duas obras - uma sagrada, outra profana - referem-se ao campo religioso. A Bíblia, por excelência o livro símbolo da cultura ocidental, aparece como uma leitura fundamental para o futuro venerável da Loja América, já habituado à presença do Evangelho de São João no altar das lojas de rito escocês, colocado lado a lado com os dois outros símbolos emblemáticos da maçonaria, o esquadro, símbolo da matéria, e o compasso, símbolo do Espírito e de seu poder sobre a matéria. Quanto à obra profana, Vida de Jesus, o historiador das origens do cristianismo procurou fazer uma interpretação racional e positiva, desvinculada de especulações metafísicas ou teológicas, a fim de reinscrever na sua historicidade um homem "sublime, que ainda $[\ldots]$ preside o destino do mundo" (Renan, 1996, p.405). O Cristo, escreve Renan, é um indivíduo que, mesmo não sendo Deus, "propiciou à sua espécie o maior passo em direção ao divino"; aparece, portanto, como o maior dentre os "filhos dos homens" a quem ensinou a "criar, afirmar e agir", colocando o "interesse pela humanidade" acima das "vaidades mundanas" (ibidem, p.405-6). Embora escrevesse a seu filho na urgência, os livros recomendados, entre tantas escolhas possíveis para aquele leitor culto e voraz, evidenciava o valor do exemplo representado pelo personagem que encarna a humana perfeição.

Entre os admiradores de Renan encontram-se, naturalmente, indivíduos pertencentes a campos adversários, como o próprio imperador, fino conhecedor de filologia hebraica, razão que não impede Luiz Gama de experimentar também um coup de foudre por uma obra que, ditada pelo racionalismo, provocou escândalo e ruptura com a doutrina cristã. Nomeado professor de hebraico no reputado Collège de France em 1862, Renan é expulso logo após a primeira aula em que apresentou sua interpretação de Jesus, não como o Messias, mas simplesmente como um homem excepcional, único na história da humanidade. Luiz Gama inclui-se, pois, precocemente entre as centenas de leitores brasi- 
leiros de Vida de Jesus, um dos maiores sucessos editoriais da segunda metade do século XIX, traduzido logo após seu lançamento em 1863 para mais de dez línguas (Renan, 1974, p.531). Contrariamente a toda uma geração de letrados pertencentes a uma elite social e econômica, como Nabuco (1948, p.xiii), que encontrara Renan em Paris e para quem o francês era a língua do "alimento intelectual que a língua natal não the podia ainda fornecer", o autodidata Luiz Gama nunca viajou para o exterior e não conhecia línguas estrangeiras. ${ }^{14} \mathrm{Sem}$ acesso ao original em francês, como teria efetuado a leitura de uma obra por ele considerada essencial?

No Brasil, Vida de Jesus e seu autor seriam rapidamente conhecidos e comentados. As polêmicas teses de Renan, por muitos consideradas heterodoxas, quando não francamente iconoclastas, acenderam tanto o entusiasmo de seus adeptos quanto a fúria dos opositores. É bem provável que uma boa parte dos interessados tenha lido em francês essa obra que abalaria a crença dogmática no catolicismo. Outros leitores talvez não se tenham privado de sua leitura, supondo-se que Vida de Jesus, uma tradução portuguesa publicada em 1864, bem como uma biografia do autor publicada no mesmo ano em Portugal não tenham demorado a chegar ao Brasil, onde essa obra ganhou, nos dias de hoje, um insólito interesse, já que só há pouco mais de dez anos recebeu sua primeira tradução brasileira. ${ }^{15}$ Entretanto, o maître à penser que diz escrever para "aqueles que buscam a verdade", não se importando com os que o julgam "um homem de má fé" (Renan, 1974, p.34), não é só alvo de admiração. As obras de repúdio às suas idéias desembarcam no Brasil e foram traduzidas com espantosa rapidez. Ainda em 1864, sai na Bahia, com o título revelador de Refutação ao romance d'Ernest Renan, uma tradução do Examen critique de la Vie de Jésus (1863), de autoria do monsenhor Charles-Émile Freppel. ${ }^{16}$ Bispo na cidade de Angers, o eclesiástico ministra, à época, aulas de eloqüência sagrada na Sorbonne e assina uma das primeiras críticas sistemáticas à nova interpretação do personagem de Jesus.

Para responder à nossa pergunta, portanto, a hipótese mais verossímil nos faz pensar que Luiz Gama e outros leitores da província de São Paulo tenhamse referido a um texto praticamente desconhecido. Trata-se de $A$ vida de Jesus por Ernesto Renan, publicada em Santos no mesmo ano em que sai a obra em Portugal (Renan, 1864b). ${ }^{17}$ Reforça a nossa hipótese o fato de não termos encontrado nenhum exemplar da tradução portuguesa durante nossas buscas nas principais bibliotecas de São Paulo, autorizando-nos, pois, a supor que a versão organizada em Santos tenha sido das únicas, se não a única, a permitir o acesso à obra, particularmente, aos paulistas. ${ }^{18} \mathrm{O}$ fator geográfico (cidade portuária, proximidade com a capital sede de uma instituição de ensino superior) associado ao modo como foi preparada a edição da tradução brasileira devem ter sem dúvida contribuído para que o livro entrasse rapidamente em circulação, ao menos no plano local. Por razões de economia, decerto, e no intuito de aliviar a leitura de uma obra original, farta em notas, o editor ou a pessoa encarregada pelo estabe- 
lecimento do texto adverte os leitores que, na verdade, eles encontrarão ali um "resumo" e a tradução dos trechos mais significativos do original. O que chamaríamos de infidelidade justificada do tradutor guiou as escolhas que o fizeram retirar a totalidade das riquíssimas e elucidativas notas de rodapé, dois capítulos dedicados às contextualizações históricas e os trechos contendo descrições do meio físico onde evoluía Jesus. O primeiro capítulo, redigido pelo responsável pela publicação, enaltece tanto os méritos quanto o método científico de um estudioso que, mesmo dando provas de "autoridade", atraiu a iracúndia dos cristãos em vários países (ibidem, p.3). Ao personagem legendário construído pelo maravilhoso cristão, Renan, apóstolo da razão, opunha a figura do "homem incomparável", sim, porém fruto da história. E é esse "Homem-Cristo", síntese de "tudo o que há de bom e elevado na nossa natureza" (Renan, 1974, p.426), que o abolicionista brasileiro, na carta ao filho, erigiu em modelo.

Em escritos posteriores, Luiz Gama continuaria evocando o Jesus retratado por Renan com colorações humanitárias, o homem que lutou para e ao lado dos pobres, encarnando os ideais de um comunismo nascente e já estigmatizado. Em 27 de agosto de 1876, na seção "Máximas à pressa" do semanário O Polichinelo, seu proprietário e redator enuncia concisamente um paradoxo: "Cristo estabeleceu o comunismo para a salvação da sociedade; a sociedade salva proscreve o comunismo por amor de Cristo". Se Renan delineia um Cristo envolvido numa aura romântica e a ser imitado sem arrogância, Luiz Gama, homem de seu tempo, funda sua ética sobre esse modelo considerado por alguns como uma das grandes criações francesas do século XIX (ibidem, p.26). Na carta dirigida a Lúcio de Mendonça em 1880, o abolicionista "incomparável" faz o balanço dos esforços que empreendera sem trégua por mais de doze anos: "[no] foro e [na] tribuna [...] ganho o pão para mim e para os meus, que são todos os pobres, todos os infelizes; e para os míseros escravos, que, em número superior a 500, tenho arrancado às garras do crime (Gama in Moraes, 2005, p.75).

Para Luiz Gama e outros correligionários que com ele compartilham, além das idéias, a mesma ética, a pobreza é um valor moral. O autor de sátiras políticas e sociais o declara num de seus poemas: "Amo o pobre, deixo o rico/Vivo como o Tico-tico..." (Gama, 2000, p.113); aos leitores dos jornais paulistanos, ele se proclama "quaker ou taciturno ebionita" (do hebraico evionim, ou "pobre") (Gama, 1944, p.183). Em 1882, durante seu funeral, tido como o maior até então já havido na capital paulista, os elogios fúnebres e as homenagens de seus companheiros louvavam a extrema pobreza do homem para quem o direito não era um simples meio de vida, mas o meio para cumprir uma missão filantrópica e redentora. Abolicionista convicto e membro fundador de uma caixa emancipadora batizada com o nome de Luiz Gama poucas semanas antes de sua morte, ninguém menos do que o estudante Raul Pompéia encarregou-se de tecer-lhe a crônica dos últimos dias:

Luiz Gama fazia tudo: libertava, consolava, dava conselhos, demandava, sacrificava-se, lutava, exauria-se no próprio ardor, como uma candeia iluminando à custa 
da própria vida as trevas do desespero daquele povo de infelizes, sem auferir uma sombra de lucro, entendendo que advogado não significa o indivíduo que vive dos jantares que lhe paga Têmis; entendendo que deve-se fazer um pouco de justiça grátis. E, com esta filosofia, empenhava-se de corpo e alma, fazia-se matar pelo bem. O herói...

Pobre, muito pobre, deixava para os outros tudo o que lhe vinha das mãos de algum cliente mais abastado; doente, moribundo, encontrava no âmago da sua natureza uma reserva instintiva de energia, e ia gastá-la em proveito da justiça e da beneficência oculta, avessa à fanfarra das reclames, sublime. Tudo isto conglobava-se-me no espírito, como uma grande esfera de luz, sobre a qual levantavase a figura nobre, irresistível do bom Luiz Gama. Havia para ele como que um trono em minha alma. ${ }^{19}$

O tom emocionado e o teor desse depoimento parecerão excessivos ou sem sentido nos dias de hoje, quando parecem banalizar-se a indiferença e a prevaricação... Contudo, há cerca de 130 anos, tinha-se no Brasil um Luiz Gama identificado com o Jesus de Renan, o homem que se sentia à vontade no meio do povo e dos indivíduos abandonados pelo judaísmo ortodoxo, o homem cujos discípulos galileus apreciavam ser chamados, também, de “ebionitas” (Renan, 1974, p.233 e 235 ).

Se a leitura de Renan marca a consciência de dois homens dedicados à campanha em prol da abolição no Brasil, é forçoso observar que ela não ensejou nem uma aproximação maior entre eles nem afinidades ideológicas sobre as formas a serem seguidas pelo movimento.

Pode-se estranhar o fato de Luiz Gama jamais ter mencionado o nome de Joaquim Nabuco em nenhum de seus escritos. É também curioso que esses dois destacados líderes da luta antiescravista aparentemente nunca se tenham encontrado, embora durante seus estudos em São Paulo Nabuco tivesse, como Rui Barbosa, freqüentado a Loja América, bem como outros círculos, literários ou políticos, dos quais participava Luiz Gama (Ferreira, 2001, p.326). Seguindo os conselhos que the prodigalizara Renan, Nabuco (1988, p.90-2 e 28) faz-se historiador e escreve uma vasta crônica do abolicionismo, na qual, partidário da emancipação dos escravos pela via parlamentar, menciona en passant a atuação do abolicionista negro, sem destacar-lhe nenhum papel pioneiro. Por parte de Luiz Gama, pesa o mesmo estranho silêncio, originado sem dúvida pelo fato de colocar o conselheiro Nabuco de Araújo, ex-presidente da província de São Paulo e pai de Joaquim Nabuco, entre as autoridades anuentes com a escravização ilegal de africanos. ${ }^{20}$

Quanto aos métodos de luta, os pontos de vista dos dois abolicionistas são diametralmente opostos, quiçá em virtude do locus socioeconômico e racial a partir do qual pensam, falam, agem e enxergam a mais grave e complexa questão do Brasil. Em artigo publicado na Gazeta do Povo em 28.12.1880, o ex-escravo Luiz Gama, àquela altura representante legítimo do direito, mal disfarça a impa- 
ciência que o desgarra de seus correligionários e da própria Justiça, perante um regime servil que se eterniza, e pelo qual parece disposto a seguir um caminho revolucionário:

Eu, assim como sou republicano, sem o concurso dos meus valiosos correligionários, faço a propaganda abolicionista, se bem que de modo perigoso, principalmente para mim e de minha própria conta.

Estou no começo: quando a Justiça fechar as portas dos tribunais, quando a prudência apoderar-se do país, quando nossos adversários ascenderem ao poder, quando da imprensa quebrarem-se os prelos, eu saberei ensinar aos desgraçados a vereda do desespero.

Basta de sermões, acabemos com os idílios [...]

Ao positivismo da macia escravidão eu anteponho o das revoluções da liberdade; quero ser louco como John Brown, como Espártacus, como Lincoln, como Jesus; detesto porém, a calma farisaica de Pilatos. ${ }^{21}$ (grifo nosso)

Os modelos citados não são inocentes. Na mesma época em que Gama cogita incitar os escravos à rebelião, a idéia de um movimento popular, desorganizando as fazendas e outros setores da sociedade, repugnava a Nabuco. Ele encabeça um movimento cuja responsabilidade, a seus olhos, caberia unicamente aos políticos a fim de preservar de uma "vindita bárbara e selvagem" as camadas mais “influentes e poderosas do Estado”, das quais, aliás, é filho. Sua posição é clara:

A propaganda abolicionista [...] não se dirige aos escravos. Seria um [...] suicídio político para o partido abolicionista incitar à insurreição ou ao crime homens sem defesa, e que ou a lei de Lynch ou a justiça pública imediatamente havia de esmagar [... Seria o sinal da morte do abolicionismo de Wilberforce, Lamartine e Garrison, que é o nosso, e o começo do abolicionismo de Catilina ou de Spartacus, ou de John Brown... (Nabuco, 1988, p.25 - grifo nosso)

Nabuco alude aos mesmos nomes que Luiz Gama, para, no entanto, rejeitá-los, como se dessa forma desejasse dar uma resposta ou desacreditar uma ação contrária à sua, como a empreendida por Luiz Gama e seu grupo. Esses homens representam a vanguarda do movimento que, em São Paulo, após a morte do advogado dos escravos, se radicalizaria inspirando a ação de Antonio Bento e dos Caifases.

Vemos, assim, que, no Brasil, a longa influência de Renan, hoje um tanto ignorada, não é desprovida de contradições e se exerce de modo desigual em homens que, mesmo atribuindo-lhe o papel de mâtre à penser, situam-se em campos opostos, possuem destinos e sensibilidades divergentes. Nesse sentido, uma rápida comparação entre Gama e Joaquim Nabuco era inevitável e pode ser ainda mais aprofundada. Em virtude de sua origem racial e social, de suas escolhas políticas e ideológicas e, enfim, de sua visão do processo que deveria desembocar na abolição, o ex-escravo Luiz Gama encontra-se nas antípodas de um aristocrata como Joaquim Nabuco (1948, p.79) que se arvora no "mais inteiramente sugestionado dos nossos renanistas". Uma afirmação, quiçá, em tempo de ser revista. Da mesma forma, cumpre apontar os limites da influência 
de Renan sobre Luiz Gama, já que ele parece ignorar o Renan teórico das diferenças raciais cujas idéias fazem coro com o darwinismo social. Contando com o desaparecimento das raças inferiores no futuro, o autor de Qu'est-ce qu'une nation? sonhava com uma humanidade racialmente homogênea, para a aflição de seus seguidores brasileiros, convictos, na virada do Império para a República, de que era preciso embranquecer o país a qualquer preço.

\section{Notas}

1 Este artigo é uma versão ampliada da comunicação "Luiz Gama (1830-1882) et Ernest Renan (1823-1892): le mouvement abolitionniste au Brésil", apresentada no Colóquio "L'influence d' Ernest Renan sur le débat idéologique au Brésil fin 19 'me et début 20 ème", realizado em 7 de outubro de 2005 em Rennes, França.

2 Ver “Carta a Lúcio de Mendonça” em Moraes (2005, p.67-75). Nesse documento, datado de 25 de julho de 1880, Gama traz revelações sobre sua família e sua infância na Bahia. Encontra-se também reproduzido em Menucci (1938, p.19-26).

3 Carta de 26 de junho de 1856, parabenizando o autor de Essai sur l'inégalité des races humaines (1853), em Renan (1992, p.221).

4 Recentemente, organizamos a edição da obra poética completa de Luiz Gama, levando em conta as duas edições publicadas com o autor ainda em vida e reunindo também os poemas publicados na imprensa (Gama, 2000).

5 Em 1867, Agostini instala-se no Rio de Janeiro, onde cria a Revista Ilustrada (18761891), o mais importante órgão da imprensa humorística e política do século XIX no Brasil. Nas páginas desse periódico, considerado por Nabuco como a "Bíblia abolicionista do povo que não sabe ler", encontram-se alguns artigos assinados por Luiz Gama, bem como artigos em sua homenagem, antes e depois de sua morte.

6 Ver "Pela última vez", Correio Paulistano, 3.12.1869 (Gama, 1944, p.183).

7 Ibidem (Gama, 1944).

8 Seção “Nomes e definições”, O Polichinelo, n.20, 27.8.1876.

9 O Radical Paulistano era dirigido por Luiz Gama, Américo de Campos e Bernardino Pamplona de Menezes e contava com Rui Barbosa, iniciando-se como jornalista, entre seus colaboradores

10 Durante o I Congresso Republicano da província, realizado em julho de 1873 em São Paulo, com a participação de quase trinta representantes de municípios, sobressairia a intervenção fulminante de um Luiz Gama indignado por encontrar naquelas hostes os fazendeiros escravocratas que combatia e que reivindicavam, por meio de manifesto, a emancipação lenta e gradual dos escravos, bem como indenização de seus bens, em nome dos direitos adquiridos e da proteção à propriedade. Embora tivesse seu voto vencido, para o incansável advogado dos escravos, tratava-se de uma traição ideológica, já que para ele e outras figuras ortodoxas o fim da escravidão constituía-se num dos pilares dos ideais republicanos. O episódio é narrado no ensaio biográfico de Luiz Gama realizado por Lúcio de Mendonça (1880). Por essa razão, distanciar-se-ia do influente partido paulista, convertendo-se em personagem emblemática dos republicanos abolicionistas, conforme o retrataram tanto Raul Pompéia quanto Lúcio de Mendonça. 
11 A título de comparação, o número de escravos no Nordeste em 1864 é de aproximadamente 774 mil (ou seja, $45 \%$ do número total de escravos no Brasil), e de 435.687 (ou seja, $28 \%$ do total) em 1874. Durante o mesmo período, nas regiões cafeeiras, o número de escravos aumenta de 645 mil (43\% do total) para 809.575 ( $56 \%$ do total).

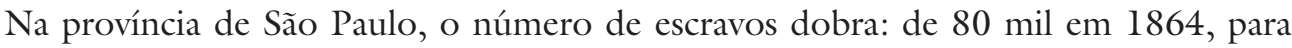
$174.622 \mathrm{dez}$ anos depois (cf. Fausto, 1994, p.204).

12 Coincidência ou não, trata-se do momento em que o autor de $O$ abolicionismo, quase sempre lacônico sobre a atuação sistemática e organizada dos paulistas, encontra-se ele próprio à frente de um grupo de abolicionistas no Parlamento.

13 Segundo Serbanesco (1964, p.201), na iniciação do Mestre ou do terceiro grau, ouvese a recomendação: “Trabalha e persevera e serás recompensado... ".

14 Ver o poema “No álbum do Sr. Capitão João Soares”, em Gama (2000, p.88): “Das línguas estranhas / nenhuma aprendi / ...".

15 Cf. Renan (1864a), Carfort \& Bazouge (1864) e Renan (1996). O interesse atual despertado pela obra de Renan no Brasil reflete alguns aspectos relativos à sua recepção e ao tema. No prefácio, o editor especializado em temas religiosos assinala que jamais houve uma edição brasileira, e que, até então, os leitores brasileiros só tiveram acesso ao livro por meio de raras edições portuguesas. Ao traduzir integralmente Vida de Jesus, Claret acredita preencher uma lacuna "inexplicável" e cumprir um dever "religioso e cultural" ao atender à demanda crescente de leitores interessados pelo Jesus humano do historiador bretão.

16 Cf. A vida de Jesus: refutação do romance A vida de Jesus pelo Padre Freppel (1864).

17 Exemplar consultado na Biblioteca Mário de Andrade, em São Paulo.

18 Não localizamos exemplares de traduções portuguesas da obra de Renan nas principais bibliotecas paulistas (Mário de Andrade, Instituto de Estudos Brasileiros). A Fundação Biblioteca Nacional possui exemplar da tradução portuguesa de 1864.

19 Cf. "Última página da vida de um grande homem”, Gazeta de Notícias, 10.9.1882 (in Pompéia, 1982).

20 Cf. Luiz Gama, "Questão jurídica”, A Província de São Paulo, 18.12.1880 (Gama, 1944, p.188-99).

21 Cf. Luiz Gama, “A emancipação ao pé da letra”, Gazeta do Povo, 28.12.1880.

Referências bibliográficas

A VIDA DE JESUS: refutação do romance A vida de Jesus pelo Padre Freppel. Bahia: Camilo Lelis Masson, 1864

ADORNO, S. Os aprendizes do poder. O bacharelismo liberal na política brasileira. Rio de Janeiro: Paz e Terra, 1988.

BESOUCHET, L. Renan e o imperador do Brasil. In: La Bretagne, le Portugal, le Brésil. Echanges et rapports. Actes du Cinquantenaire de la création en Bretagne de l'enseignement du portugais, Université de Haute Bretagne, Université de Bretagne Occidentale, Université de Nantes, 1973, p.331-58.

BRUNO, E. da S. História e tradições da cidade de São Paulo. Rio de Janeiro: José Olympio, 1953. 
CABRIÃO. Semanário humorístico editado por Ângelo Agostini, Américo de Campos e Antônio Manoel dos Reis: 1866-1867. 2.ed. São Paulo: Editora Unesp, Imprensa Oficial, 2000.

CARFORT, A. de; BAZOUGE, F. Biografia de Ernesto Renan. Trad. e editor J. L. Rodrigues Trigueiro. Lisboa: s. n., 1864.

DIABO COXO. São Paulo, 1864-1865, redigido por Luiz Gama. São Paulo: Editora da Universidade de São Paulo, 2005.

COMPARATO, F. K. Luiz Gama, herói do povo brasileiro. Folba de S.Paulo, 13.5.2007.

FAUSTO, B. História do Brasil. São Paulo: Edusp, 1994.

FERREIRA, L. F. Luiz Gama (1830-1882): étude sur la vie et l'auvre d'un Noir citoyen, militant de la lutte anti-esclavagiste au Brésil. Paris, 2001. 4v. Tese (Doutorado) - Universidade de Paris 3 / Sorbonne Nouvelle.

GAMA, L. Primeiras trovas burlescas de Getulino. São Paulo: Tipografia Dois de Dezembro de Antônio Louzada Antunes, 1859. 130p.

. Primeiras trovas burlescas de Getulino. 2.ed. correta e aumentada. Rio de Janeiro: Tipografia de Pinheiro e Cia., 1861. 252p.

. A emancipação ao pé da letra. Gazeta do Povo, 28.12.1880.

. Trovas burlescas \& escritos em prosa. Texto organizado por Fernando Góes. São Paulo: Edições Cultura, 1944.

. Primeiras trovas burlescas \& outros poemas. Org. e introd. Ligia Fonseca Ferreira. São Paulo: Martins Fontes, 2000.

MENDONÇA, L. de. Luiz Gama. In: LISBOA, J. M. Almanaque Literário de São Paulo para o ano de 1881. São Paulo: Tipografia da "Província", 1880. p.50-62.

MENUCCI, S. O precursor do abolicionismo no Brasil. São Paulo: Cia. Editora Nacional, 1938.

MORAES, M. (Org.) Antologia da carta no Brasil: me escreva tão logo possa. São Paulo: Moderna, 2005.

NABUCO, J. Minha formação. Prefácio de Carolina Nabuco. Rio de Janeiro, São Paulo, Porto Alegre: W. M. Jackson Inc., 1948.

O abolicionismo. Prefácio de José Thomaz Nabuco. Recife: Fundaj, Massangana, 1988.

O POLICHINELO, n.20, 27.8.1876.

POMPÉIA, R. Obras. Org. Afrânio Coutinho. Rio de Janeiro: Civilização Brasileira, Oficina Literária Afrânio Coutinho, Fename, 1982.

REIS, J. J. Rebelião escrava no Brasil. São Paulo: Cia. das Letras, 2003.

RENAN, E. Vida de Jesus. Trad. Jacinto Augusto Xavier de Magalhães. 2.ed. Lisboa: Salles, 1864a.

. Vida de Jesus (extrato). Santos: Tipografia Comercial, 1864b. 72p.

. Vie de Jésus. Édition établie, présentée et commentée par Jean Gaulmier. Paris:

Gallimard, 1974. 
RENAN, E. Qu'est-ce qu'une nation? et autres textes politiques. Paris: Presses Pocket, 1992. - Vida de Jesus (Origens do Cristianismo). Prefácio da edição brasileira por Martin Claret. São Paulo: Martin Claret, 1996.

ROMERO, S. Explicações indispensáveis. Prefácio. In: BARRETO, T. Vários escritos. s. 1.: Ed. do Estado de Sergipe, 1926. p.xxiii-xxiv.

SERBANESCO, G. Histoire de la franc-maçonnerie universelle. Beauronne (Dordogne): Les Éditions Intercontinentales, 1964.

VERÍSSIMO, J. Homens e coisas estrangeiras. Rio de Janeiro: Topbooks, 2003.

RESUMO - O hisoriador e filósofo Ernest Renan exerceu grande influência, hoje um tanto esquecida, sobre uma boa parte da elite intelectual brasileira engajada em reformas e movimentos que caracterizam a transição da Monarquia para a República. Dentre eles, destaca-se o abolicionista Luiz Gama, caso único de um ex-escravo autodidata que alcança projeção no cenário político e na República das Letras. Leitor precoce de Vida de Jesus, obra seminal do pensador francês, o advogado dos escravos é um dos primeiros a referir-se à obra que contou com inédita tradução brasileira, pouco depois de sua publicação na França. Por fim, observamos a apropriação das idéias renanianas por parte de personalidades diversas do ponto de vista social e racial, estabelecendo um paralelo entre Luiz Gama e Joaquim Nabuco.

PALAVRAS-CHAVE: Luiz Gama, Ernest Renan, Joaquim Nabuco, Abolicionismo, Republicanismo, Escravidão, Maçonaria, São Paulo século XIX, Vida de Jesus.

ABSTRACT - Historian and philosopher Ernest Renan exerts great influence - today somewhat forgotten - on a large part of the Brazilian intellectual elite that is engaged in reforms and movements which characterize the transition of a Monarchy to a Republic. Among these, abolitionist Luiz Gama stands out as the sole case of a former autodidact slave, who achieves a projection in the political scenario, and in the Republic of Letters. An early reader of Vida de Jesus, a seminal work of the French philosopher, the slaves' attorney is one of the first to refer to the work, which counted with a first-hand, unprecedented Brazilian translation, shortly after its publication in France. Finally, we shall see the appropriation of Renanian ideas on the part of various personalities from the social and racial point of view, while establishing a parallel between Luiz Gama and Joaquim Nabuco.

KErWORDS: Luiz Gama, Ernest Renan, Joaquim Nabuco, Abolitionism, Republicanism, Slavery, Free-masonry, $19^{\text {th }}$ Century São Paulo, Vida de Jesus.

Ligia Fonseca Ferreira é professora da Universidade de São Paulo, com doutorado na Universidade de Paris 3 - Sorbonne sobre a vida e a obra de Luiz Gama. Organizou a edição das poesias completas desse autor: Primeiras trovas burlescas \& outros poemas (Martins Fontes, 2000). @-ligia.ff@uol.com.br

Recebido em 28.5.2007 e aceito em 10.6.2007. 